\title{
Prospective study of 393 adolescent thoracic hyperkyphosis patients treated by the Lyon method
}

\author{
Jean Claude de Mauroy*, Didier Fort \\ From 10th International Conference on Conservative Management of Spinal Deformities - SOSORT 2013 \\ Annual Meeting \\ Chicago, IL, USA. 8-11 May 2013
}

\section{Background}

Unlike scoliosis, there is no alteration in respiratory function with hyperkyphosis [1]. The resulting problems are mainly related to aesthetics and pain. The various conservative orthopedic treatments were discussed at the 7th SOSORT consensus session [2]. Is bracing useful to improve aesthetics and prevent back pain?

\section{Purpose}

A retrospective study was presented at the SOSORT Montreal [3]. The good results observed were complemented by a prospective study performed on our entire database of orthopedic medicine between 1998 and 2007.

\section{Methods}

The Lyon method includes:

- A reduction with plaster cast for a minimum of 1 month to increase the length of the anterior longitudinal ligament (creep).

- An immobilization in a corrected position by a plexidur 5 points brace worn at minimum during the night.

- A specific physiotherapy.

\section{Results}

Conservative treatment was indicated in 393 patients.

- $27 \%$ of patients do not accept the proposed treatment or interrupt it spontaneously.

- 23\% of patients have a physiological angulation less than $44^{\circ}$ at the end of treatment.

\footnotetext{
* Correspondence: demauroy@aol.com

Clinique du Parc, Lyon, France
}

- $43 \%$ of patients were reviewed two years after removal of the brace.

The initial kyphosis angle was $60.5^{\circ}$.

The final angulation 2 years after removal of the brace was $41^{\circ}$.

Among the 262 patients who performed the full treatment:

- All patients who had pain before treatment were relieved of that pain after treatment began.

$-79 \%$ were fully corrected with final angulation $<45^{\circ}$.

- $17 \%$ were stabilized with a final angulation between $45^{\circ}$ and $55^{\circ}$.

- $11 \%$ retained an angle of $>55^{\circ}$ and can be considered as treatment failures.

In total, 222 patients were reviewed more than 10 years after removal of the brace. The angle remains stable in 21 cases.

\section{Conclusions and discussion}

The Lyon method is difficult for the patient and onethird of patients did not accept it.

Unlike scoliosis, which is stabilized by orthopedic treatment, it is possible to restore a physiological kyphosis in the sagittal plane.

Published: 18 September 2013

\section{References}

1. Stagnara P, de Mauroy JC, Dran G, Gonon GP, Costanzo G, Dimnet J, Pasquet A: Reciprocal angulation of vertebral bodies in a sagittal plane: approach to references for the evaluation of kyphosis and lordosis. Spine (Phila Pa 1976) 1982, 7(4):335-42.

2. de Mauroy JC, Weiss HR, Aulisa AG, Aulisa L, Brox JI, Durmala J, Fusco C, Grivas TB, Hermus J, Kotwicki T, Le Blay G, Lebel A, Marcotte L, Negrini S, Neuhaus L, Neuhaus T, Pizzetti P, Revzina L, Torres B, Van Loon PJM, Vasiliadis E, Villagrasa M, Werkman M, Wernicka M, Wong MS, Zaina F: 7th

\section{Clinique du Parc, Lyon, France}


SOSORT consensus paper: conservative treatment of idiopathic \& Scheuermann's kyphosis. Scoliosis 2010, 5:9, doi:10.1186/1748-7161-5-9.

3. de Mauroy JC, VallÄ"se P, Fender P, Lecante C: Historical Lyonaise brace treatment for adolescent hyperkyphosis. Results of 272 cases reviewed two years minimum after removal of the brace. Scoliosis 2010, 5(Suppl 1): O69, doi: 10.1186/1748-7161-5-S1-069.

doi:10.1186/1748-7161-8-S2-050

Cite this article as: Claude de Mauroy and Fort: Prospective study of 393 adolescent thoracic hyperkyphosis patients treated by the

Lyon method. Scoliosis 2013 8(Suppl 2):O50.

Submit your next manuscript to BioMed Central and take full advantage of:

- Convenient online submission

- Thorough peer review

- No space constraints or color figure charges

- Immediate publication on acceptance

- Inclusion in PubMed, CAS, Scopus and Google Scholar

- Research which is freely available for redistribution

Submit your manuscript at www.biomedcentral.com/submit
C Biomed Central 